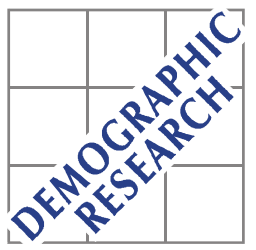

Demographic Research a free, expedited, online journal

of peer-reviewed research and commentary in the population sciences published by the Max Planck Institute for Demographic Research

Konrad-Zuse Str. 1, D-18057 Rostock · GERMANY

www.demographic-research.org

DEMOGRAPHIC RESEARCH

VOLUME 27, ARTICLE 16, PAGES 429-454

PUBLISHED 2 OCTOBER 2012

http://www.demographic-research.org/Volumes/Vol27/16/

DOI: $10.4054 /$ DemRes.2012.27.16

Research Article

Like daughter, like son? Fertility decline and the transformation of gender systems in the family

Keera Allendorf

(C) 2012 Keera Allendorf.

This open-access work is published under the terms of the Creative Commons Attribution NonCommercial License 2.0 Germany, which permits use, reproduction \& distribution in any medium for non-commercial purposes, provided the original author(s) and source are given credit.

See http:// creativecommons.org/licenses/by-nc/2.0/de/ 


\section{Table of Contents}

1 Introduction $\quad 430$

$2 \quad$ Theoretical background $\quad 430$

$3 \quad$ Methods 435

3.1 Site 435

3.2 Data collection 438

3.3 Analysis and limitations $\quad 439$

$4 \quad$ Results $\quad 440$

$\begin{array}{lll}4.1 & \text { Fertility } & 440\end{array}$

$\begin{array}{lll}4.2 & \text { Son preference } & 441\end{array}$

4.3 Education 442

4.4 Marriage and premarital relationships 443

$4.5 \quad$ Parental support in old age 446

$5 \quad$ Discussion and conclusion $\quad 447$

$6 \quad$ Acknowledgments $\quad 449$

$\begin{array}{ll}\text { References } & 450\end{array}$ 


\title{
Like daughter, like son? Fertility decline and the transformation of gender systems in the family
}

\author{
Keera Allendorf ${ }^{1}$
}

\section{ABSTRACT \\ BACKGROUND}

An important question for population research is whether fertility decline transforms gender systems.

\section{OBJECTIVE}

This paper contributes to answering this broad question by examining how fertility decline may change the relative value and roles of daughters and sons in families. First, I outline theoretical pathways, suggesting that a key factor is the gender composition of families. As fertility declines, the proportion of families with children of only one gender increases, which may facilitate greater gender symmetry between daughters and sons. Second, I explore how fertility decline may have contributed to the transformation of the relative value and roles of sons and daughters in practice in one place.

\section{METHODS}

The analysis draws primarily on semi-structured interviews with 30 respondents living in one Indian village. This village is located in a district where fertility has declined to at least the replacement level.

\section{RESULTS}

Respondents perceive changes in the gender system, including less son preference, more equal schooling for sons and daughters, more freedom in marriage and premarital relationships, and perhaps greater daughter support of parents in old age.

\section{CONCLUSIONS}

The results describe changes in the relative value, treatment, and behavior of sons and daughters that are consistent with the theorized effects of fertility decline. Future research is needed, however, to determine whether fertility decline makes a causal contribution to changes in the gender system.

\footnotetext{
${ }^{1} \mathrm{PhD}$, Assistant Professor. Department of Sociology, University of Illinois at Urbana-Champaign, 702 S. Wright St. Urbana, IL 61801. Email: kallendo@illinois.edu.
} 


\section{Introduction}

In recent decades fertility has fallen around the world. At the beginning of the 1950s, the total fertility rate for the world population was almost five children per woman (United Nations 2011). Nearly six decades later, the total fertility rate had declined to 2.5 in 2005-10 (ibid). With fertility decline, demographers have turned their attention from the determinants of fertility to the consequences of fertility decline, including impacts on age structure, economic growth, and social life.

One aspect of social life that may be transformed by fertility decline is that of gender systems (Malhotra 2009; Mason 1997; Reher 2011). Following Mason (2001:161), I define a gender system as "a set of beliefs and norms, common practices, and associated sanctions through which the meaning of being male and female and the rights and obligations of males and females of different ages and social statuses are defined.” A few studies have examined the consequences of fertility decline and control on women's employment in Western countries (Bailey 2006; Bloom et al. 2009; Matysiak and Vignoli 2008). Beyond this work, however, the potential impact of fertility decline on gender systems has been largely overlooked. Thus, one important question for demographic research is whether fertility decline and control transform gender systems (Malhotra 2009).

This paper aims to contribute to answering this broad question by examining how fertility decline and control may transform one aspect of gender systems within the family. Specifically, this paper explores how fertility decline may change the relative value and roles of daughters versus sons in their natal families. I suggest that fertility decline facilitates greater gender symmetry between daughters and sons and greater freedom for daughters especially. I first outline a theoretical model describing potential pathways linking fertility decline to changes in the gender system. Next, drawing on semi-structured interviews, I explore how fertility decline may be transforming the value and roles of sons and daughters in practice in one Indian village.

\section{Theoretical background}

Malhotra (2009) describes three main pathways through which fertility decline may transform gender systems. The first two pathways focus on women's reproductive capacity as the fundamental motivation for the subjugation of women. First, Malhotra (2009) notes that fertility decline should reduce the fundamental motivation to control women because their reproductive capacity becomes less valuable as large numbers of children become less desirable. Second, the ability to control fertility through the use of effective contraception separates sex from childbearing. As effective means of 
contraception become available, women and their partners can increasingly engage in sex without fear that a pregnancy will result (Presser 2001). This separation should further reduce the underlying motivation to control women and their sexuality.

Malhotra's (2009) third pathway points to a more mundane impact of fertility decline on women's daily lives. As fertility declines, women devote less time to bearing and rearing children, and thus have more time to expand their roles beyond motherhood. With mortality decline, women also live longer past their reproductive years providing even more time over the life course. Others have also pointed to this pathway. Reher (2011) includes the smaller amount of time spent bearing and rearing children contributing to a transformation of women's roles in his framework of how the demographic transition results in social and economic change. Similarly, the literature on women's employment in Western countries suggests that fertility decline increases women's employment because women are able to devote less time to bearing and rearing children (Bloom et al. 2009; Engelhardt, Kogel and Prskawetz 2004).

These pathways present two main mechanisms that are relevant to the focus on sons and daughters in the family. First, the decline in the fundamental motivation to subjugate women should, over the long term, contribute to greater gender equality as a whole, which includes greater similarity in the roles of sons and daughters. Second and more specifically, these pathways point to a decline in control over women's sexuality, or conversely, a rise in women's sexual freedom. In India and many other places, the sexuality of daughters is strictly controlled by ensuring that daughters have limited contact with men outside the family, do not engage in sex before marriage, and that when they do marry and have sex they do so with an approved partner. Thus, Malhotra's framework suggests that when fertility declines control over daughters' sexuality should also decline and daughters should have more contact with men, more freedom to engage in relationships outside of marriage, and marry if and as they choose.

These pathways focus on adult women engaged in childbearing. When the focus is shifted from mothers to children, however, additional pathways by which fertility decline may transform gender systems become apparent. First, fertility decline results in a smaller number of children in families. As the number of children declines, the number and likelihood of a child having siblings also declines. Second, the gender composition of children in families shifts. As fertility falls, the proportion of families with children of both genders declines, while the proportions of families with only daughters and only sons increase. For example, the biological probability of having children of both genders falls from $94 \%$ with a family of five children to $50 \%$ in a family of two. Guilmoto (2009) calls this reduced probability of having a son with fewer births the "fertility squeeze".

These changes in the composition of families may facilitate greater gender symmetry between sons and daughters. First, the decline in numbers should increase 
families' investment in daughters more than in sons, resulting in greater equality of investments between sons and daughters. When families have smaller numbers of children, they have more resources for each child (Desai 1995). With fewer children, families are better able to meet the needs of all their children, even in times of scarcity, and the neglect of daughters should decline. Further, it is not daughters in general that are neglected or unwanted, but specifically high birth order daughters. The majority of women do want one daughter and it is high birth order daughters that are at a greater risk of poor health and mortality (Arnold, Choe and Roy 1998; Mishra, Roy and Retherford 2004; Pande 2003). As fertility declines, the proportion of girls that are wanted first daughters will increase. Das Gupta and Bhat (1997) refer to this pattern as the "parity effect" of fertility decline.

The reduction in the number of siblings may provide a particular boost for investments in girls' schooling more than in boys'. Unlike sons, older daughters are often responsible for taking care of younger siblings. When daughters have no younger siblings or only one younger sibling there is less need to keep daughters at home and parents may be more likely to send them to school. Thus, Grant and Behrman (2010) speculate that fertility decline may have played an important role in reducing the global gender gap in schooling. In keeping with their suggestion, Ye and $\mathrm{Wu}$ (2011) find that the reduction in the number of siblings due to fertility decline in China did increase schooling among younger cohorts of girls.

The accompanying shift in the gender composition of families should create additional pressures for gender symmetry between sons and daughters. Families with children of only one gender are less able to make gendered distinctions among their own children. Put simply, if parents do not have a son, they cannot give more resources to a son. Having children of only one gender may also encourage parents to treat children more gender symmetrically even when not forced to by circumstance. For example, parents with only daughters could encourage all of their daughters to take on traditional feminine roles and be devoted wives and mothers. Since they have no son to succeed in the world, however, they may instead encourage one or more of their daughters to take on a high status occupation as they would have a son. More broadly, parents may be more likely to transmit gendered interests or skills to children of the opposite gender if they do not have children of the same gender. For example, a father with no sons might share his love of sports with a daughter and a mother with no daughters might share her cooking secrets with her son. Initially, these more genderneutral practices may consist largely of parents accepting birth outcomes that they perceive as less than ideal. They would have preferred to have a son, but they accommodate having only daughters. However, over time such accommodation may shift towards greater valuation of daughters and even indifference towards the gender of children. Further, such gender-neutral practices may spread from families with children 
of only one gender to the rest of the community as they become more common and accepted.

The substantial proportion of families with only daughters that will eventually emerge after fertility declines should also present a fundamental threat to the patrilineal family system, which underlies the gender system in many parts of the world (Chakraborty and Kim 2010). Under the patrilineal, joint family system, men remain members of their natal families their entire lives, while women transfer their primary family membership from their natal family to that of their husband's family at marriage. This family membership is reflected in patrilocal residence with women often living with their in-laws after marriage. Under the joint family system, sons are expected to take care of their parents in old age, while daughters take care of their parents-in-law in their role as daughters-in-law. Sons also inherit the family's property, while daughters do not.

Such a system works well when fertility is high and nearly all families have a son. However, it will not work well when the proportion of families without sons is substantial. A substantial proportion of daughters will have to take care of their own parents, if not co-reside with them, or the elderly will have to be supported by some other means, such as through government programs. Traditional patrilineal inheritance practices may also no longer be viable. The substantial proportion of families without sons will have to pass family property to daughters or leave family property to more distantly related men. Either way, the role of daughters and sons would become more similar as daughters become more like sons or sons lose an important dimension of their customary role. In turn, this could further destabilize patrilocal residence and the patrilineal system more broadly.

Above, I described pathways through which fertility decline may increase gender symmetry between sons and daughters by increasing the freedom and wellbeing of daughters. These pathways are also summarized in Figure 1. However, much of the previous literature describes how the fertility squeeze intensifies son preference and motivates families to discriminate more against girls (Das Gupta and Bhat 1997; Guilmoto 2009). Thus, previous literature suggests that fertility decline reduces gender equality and the wellbeing of girls, rather than increases it, as I describe. These claims are not contradictory however. It is important to take note of the timing of these changes. These claims refer to different points in time during and after a fertility transition. At first, the fertility squeeze does present a strong incentive for families to engage in more sex-selective abortion and neglect of girls. However, when the fertility transition has been in place for several years, families with small numbers of children become common, and children in these families reach adulthood. It is only later in the transition that all of the processes I describe above should take affect and outweigh the initial negative effects of the fertility squeeze. There is already evidence of just such a 
shift in the effect of fertility decline on sex ratios (Das Gupta, Chung and Li 2009; Goodkind 2011; Guilmoto 2009).

Figure 1: Pathways linking fertility decline and control to greater symmetry between sons and daughters






\section{Methods}

The empirical analysis draws on 30 semi-structured interviews collected in May 2010 that focused on people's perception of changes in family behaviors over time. The interviews were collected in the village of Pariwarbasti, which is located in Darjeeling District $^{2}$ in the state of West Bengal, India. (Pariwarbasti is a pseudonym.) The results also draw on ethnographic fieldwork carried out by the author in Pariwarbasti from September 2007 through May 2008. Approval for both the 2010 study and the earlier fieldwork were gained from Institutional Review Boards at the author's universities before data collection began. All respondents consented to participate and no ethical problems arose during fieldwork.

\subsection{Site}

Pariwarbasti is a village in the Eastern Himalayan foothills, located a few miles from the town of Kalimpong. The primary economic activity is agriculture, with rice, corn, and gladiolas comprising the main crops. Many Pariwarbasti residents own their own land or are tenants of landowners who live elsewhere. Some residents also work as daily laborers in agriculture and construction. Many men also work in other parts of India, either temporarily migrating to cities in search of jobs or working as soldiers in the Indian army.

The village contains a mix of castes and ethnic groups that are common in the rest of Darjeeling, the neighboring state of Sikkim, and Eastern Nepal. Ethnically, the village includes high caste Chhetri-Bahuns, several Tibeto-Burman groups - including Lepcha, Limbu, Tamang, and Rai - and some Dalits. It should be noted that compared to high caste Chhetri-Brahmans and other Indians living in the plains, the TibetoBurman groups, which are indigenous to the hills, customarily have more egalitarian gender relations (Morgan and Niraula 1995). Collectively, people in the area describe themselves as Nepali and speak the Nepali language. ${ }^{3}$ The village is primarily Hindu, but also includes Buddhists and Christians.

\footnotetext{
${ }^{2}$ Darjeeling is also the name of the city that is the district headquarters and the name of one of the four subdivisions in the district. I use Darjeeling to refer to the district as a whole.

${ }^{3}$ In this context, the term Nepali refers to an ethnic identity, rather than citizens of the nation of Nepal. It is comparable to Bengali or Punjabi. Gorkha is an alternative term that has been promoted by political leaders in Darjeeling to distinguish Nepalis living in India from those living in Nepal. However, the term Gorkha, or Gurkha, is also used to refer to Nepali soldiers from both Nepal and India that serve in the Indian and British armies. Gorkha is also the name of a district in Nepal. I use the term Nepali because it is commonly used by people in Pariwarbasti.
} 
In 2001, the total fertility rate in Darjeeling District was 2.1 children per woman (Guilmoto and Rajan 2002). Thus, fertility in the area was at the replacement level nearly a decade ago. More recent estimates of the total fertility rate at the district level are not available. However, fertility in West Bengal and the neighboring state of Sikkim continued to decline in the last decade (Registrar General [India] 2002, 2009). Thus, it is possible that in 2010, when the data presented here were collected, fertility was below the replacement level. ${ }^{4}$ Darjeeling's level of fertility is low when compared to India as a whole and its local region. According to Guilmoto and Rajan's (2002) estimates, India's total fertility rate was 3.2 in 2001, West Bengal's was 2.6, and Sikkim's was 3.0 (Table 1 ). ${ }^{5}$

Table 1: Total fertility rates for Darjeeling, West Bengal, Sikkim, and all India

\begin{tabular}{lcccc}
\hline & Darjeeling & West Bengal & Sikkim & India \\
\hline $2001^{\mathrm{a}}$ & 2.1 & 2.6 & 3.0 & 3.2 \\
$1991^{\mathrm{b}}$ & 3.5 & 3.6 & 4.9 & 4.3 \\
$1984-1990^{\mathrm{c}}$ & 3.0 & 3.6 & 4.3 & 4.1 \\
$1981^{\mathrm{b}}$ & 4.2 & 4.3 & 5.8 & 4.9 \\
$1974-1980^{\mathrm{c}}$ & 3.6 & 4.0 & 5.4 & 4.9 \\
\hline
\end{tabular}

Sources: ${ }^{a}$ (Guilmoto and Rajan 2002); ${ }^{\text {b }}$ Registrar General 1997); ${ }^{\text {c }}$ Bhat 1996).

Estimates from previous years indicate that fertility has declined substantially in Darjeeling in recent decades (Table 2). According to estimates using census data (Registrar General [India] 1997), Darjeeling's total fertility rate was 3.5 in 1991 and 4.2 in 1981 (Table 1). However, drawing on both census and sample registration data, Bhat (1996) provides district level estimates for roughly the same period, which are substantially smaller than the other estimates. Specifically, he estimates that Darjeeling had total fertility rates of 3.6 in 1974-80 and 3.0 in 1984-1990. Despite the lack of consistent numbers, all of the estimates point to a substantial decline in Darjeeling's total fertility rate - on the order of 1.5 to 2.1 children per woman - in the last two

\footnotetext{
${ }^{4}$ Further support for the probability of Darjeeling having below replacement fertility in 2010 comes from the comparison with Sikkim. According to the National Family Health Survey of 2005-06, Sikkim, with a total fertility rate of 2.02, is one of seven states in India to have below replacement fertility (International Institute for Population (IIPS) and Macro International 2007). Estimates consistently suggest that Darjeeling has lower fertility than Sikkim (Table 1).

${ }^{5}$ Estimates of the total fertility rate for India differ by source among the National Family Health Survey, Sample Registration System, and the Census. The estimates presented here were chosen because they were estimated using the same data and methods as the estimates of the total fertility rate for Darjeeling.
} 
decades of the twentieth century. Earlier estimates of Darjeeling's total fertility rate are unavailable, but Guilmoto and Rajan (2001) estimate that fertility has fallen steadily in Darjeeling since at least 1951.

Table 2: $\quad$ Characteristics of respondents $(\mathrm{N}=30)$

\begin{tabular}{lc}
\hline & Number \\
\hline Gender & 15 \\
Women & 15 \\
Men & \\
Life course stage & 10 \\
Unmarried & 10 \\
Married with child <10 & 10 \\
Married with married child & \\
Education & 7 \\
$0-4$ years & 7 \\
$5-9$ years & 16 \\
10+ years & \\
Caste/Ethnic Group & 7 \\
Bahun-Chhetri & 18 \\
Tibeto-Burman & 5 \\
Dalit & \\
Religion & 25 \\
Hindu & \\
Buddhist & 3 \\
Christian & 2 \\
Age & \\
$20-24$ & 10 \\
$25-49$ & 11 \\
$50-70$ & 9 \\
\hline
\end{tabular}

In keeping with Darjeeling's low fertility, contraceptive use is widespread in the district. In 2007-2008, 72\% of currently married women aged 15-49 were using contraception (IIPS 2010a). Darjeeling's contraceptive use is comparable to the rest of West Bengal, with a rate of $72 \%$ in 2007-2008 (ibid), and to neighboring Sikkim, with a rate of $70 \%$ (IIPS 2010b). These rates are all substantially higher than the national level of 55\% (ibid). Unmet need is correspondingly low in Darjeeling at 12\% (IIPS 2010a). The majority of unmet need is due to an unmet need for spacing. The mix of 
contraceptive methods in Darjeeling is typical for India as whole, with female sterilization being the dominant method. Of the women using contraception in 20072008, 55\% were sterilized, 26\% were using modern spacing methods, and $20 \%$ were using traditional methods (ibid).

\subsection{Data collection}

The sample of 30 respondents was stratified by gender and life course position. The stratification was used to capture potential differences in views by family experiences and gender. Given changes in family behaviors over time, stratifying the sample by life course position also ensured representation of the potentially divergent experiences and views of younger and older villagers. The sample thus includes five men and five women of each of the following three types: 1) Older married person with one or more married children; 2) Married person with one or more children under age ten; 3) Younger unmarried person. Within each of these stratified groups, I also included a mix of caste and education levels to help ensure that the full range of perceptions was captured. The basic characteristics of the respondents are presented in Table 2.

Selecting respondents comprised a combination of purposive and snowball sampling. First, I interviewed respondents I previously interviewed during the 2007-08 fieldwork who fit the criteria for the sample $(n=12)$. I re-interviewed people because I already had good rapport with them and detailed information on their family histories and backgrounds. Second, for the remaining respondents ( $n=18)$, I interviewed people in the village that I was aware of from previously living in the village who fit the criteria and also asked previous respondents and other village residents if they knew of people in the village that fit the criteria.

Interviews were conducted by the author in Nepali with no others present and took an hour to an hour and a half. The interviews followed a series of pre-determined, openended questions. Probes and unique follow-up questions were also interjected during interviews to elicit additional information and clarifications. The substantive questions began by going through a list of family behaviors, including childbearing, choosing a spouse, and supporting parents in old age, and asking respondents to describe what these behaviors are like in the village today and then what they were like in the past, 2025 years ago. If they said the behavior had changed, I asked why they think it is changing and how the change is affecting the lives of people in the village. For a small subset of behaviors, I also asked them what they think it will be like in the future and about their subjective evaluation of the changes: What do they like about the change? What do they not like about the change? And, why? 
It should be noted that respondents' responses about what it was like in the village 20-25 years ago are best interpreted as their views of what it was like at an imprecise time in the recent past. In the first few interviews, I attempted a third question anchored on the time around India's independence, roughly 50-60 years ago, which I asked just after the question on 20-25 years ago. However, with one or two exceptions, I found that respondents were not able to distinguish between these two time anchors in the past. It is also possible that the tedium of discussing three time periods for multiple family behaviors led to poor responses. Further, when asked the question on 20-25 years ago in reference to a particular behavior, respondents occasionally used their own time anchors, referencing their own experiences when they were young or their parents' and grandparents' experiences.

\subsection{Analysis and limitations}

The interviews were transcribed into Nepali and translated into English by native Nepali speakers. Then the author alone analyzed the transcripts by assigning codes to the text along four main domains using Nvivo. First, I coded the interviews descriptively according to family behaviors. Codes included, for example, arranged marriages, son preference, fertility, and premarital relationships. Second, the interviews were coded according to the respondents' subjective evaluations of the family behaviors, including good, bad, and neutral evaluations. These included the respondents' own evaluations, as well as the respondents' views of what other villagers thought. Third, causes of changes in family behaviors were descriptively coded as they emerged, including technology, foreign influence, Bollywood films, and economic changes. Fourth, the consequences of changes in family behaviors were descriptively coded as they emerged, including morality, social cohesion, and health. Throughout the coding process I also inductively coded other common themes that emerged in the interviews and were outside these four pre-determined domains. For example, these codes included family harmony, education, and alcohol use.

The nature of the data collection presents several limitations. First, the sample is small and not representative of Pariwarbasti or any other place. Thus, these results cannot be used to generalize to a population. Second, the interviews were all collected in one village. I believe that the results are not unique to Pariwarbasti, but future research is needed to determine if that is indeed the case. Third, people's responses may reflect the influence of social desirability. In particular, some respondents may have wanted to present the village in a positive light by emphasizing gender egalitarian views and practices. The fact that they were speaking to a foreign woman may have increased this desire. However, the young age and unmarried status of the author, as well as the 
amount of time the author lived in the village, may have lessened this pressure. Fourth, the study attempts to assess change over time by drawing solely on people's recollections and perceptions of the past and present. People's perceptions may be inaccurate because they misremember or do not know what it was like in the past. Their responses may also be influenced by ideas about what the past should have been like, and thus they may exaggerate the extent of gender inequality in the past. Finally, as discussed more below, the approach used here cannot provide evidence of a unique causal role of fertility decline.

\section{Results}

I begin the description of results by describing respondents' impressions of fertility decline in Parwarbasti and establishing that people in the village are aware of fertility decline. Next, I turn to changes in the gender system. The pathways described above point to potential changes in many areas. Below, I limit the analysis to four areas that emerged in the analysis of the interviews, which are relevant to sons and daughters in the family: son preference, education, marriage and premarital relationships, and support of parents in old age. For each of these areas, I describe the respondents' perceptions and experiences of change over time. In these descriptions I report numbers of respondents who gave different types of responses. These numbers are given to provide greater clarity and transparency about the range of responses found within the sample (Axinn and Pearce 2006). It should be emphasized that the sample is not representative of Pariwarbasti and these numbers cannot be used to generalize to a population.

\subsection{Fertility}

The respondents were well aware of fertility decline in the region. All 30 respondents said that people have fewer children today than they did in the past. When asked how many children women have these days, their responses ranged from one or two children up to a maximum of four or five. When asked how many children women in the village used to have in the past, roughly 20-25 years ago, the range of responses was much larger - ranging from four to five on the low end to twelve to thirteen on the high end. These numbers cannot be drawn on to make an inference about the beliefs of a larger population, but they do suggest that awareness of fertility decline in Pariwarbasti is widespread. 
In keeping with low levels of fertility, contraception appears to be available and widely used by married women in Pariwarbasti. It was common for women to note that they had been sterilized or planned on doing so. IUDs and birth control pills are also available free of charge in the village sub-health center. However, pills are only given out one package at a time, and thus may have been cumbersome to use on a regular basis. IUDs, pills, and other forms of contraception are also available for purchase in pharmacies in Kalimpong.

I believe, however, that contraception is difficult for unmarried women to access. In 2007-2008 I spent many weeks observing people in the health center and never saw an unmarried woman get contraception. Women had to walk into the health center relatively publicly and ask for pills or an IUD. Not only would other people in the health center see them but also neighbors would ask them why they were going to the health center. An unmarried woman would not want to publicly declare that she had a need for contraception. Indeed, it appeared that even some young married women found the process difficult. Thus, I suspect that, if they use it at all, unmarried women must purchase contraception in Kalimpong. It may also be difficult for them to walk into a pharmacy in Kalimpong and ask for contraception there and it further adds the complication of needing money. These observations, along with what appears to be a high rate of premarital pregnancy, which I discuss below, suggest that it is not common for unmarried women to use contraception.

\subsection{Son preference}

In Pariwarbasti respondents suggested that son preference is non-existent or rare these days. ${ }^{6}$ When asked about the value of sons versus daughters in the village today, 22 respondents said that daughters are equal to sons, three respondents said daughters are preferred, and one said sons are preferred. ${ }^{7}$ The following quote from a 59-year-old man is typical of the respondents' statements that boys and girls are equal: "They are treated equally in our village. Girls are given equal value to boys. There is no discrimination.” Two respondents also contrasted the equality of sons and daughters in Pariwarbasti to inequality among other Indian groups - namely Muslims and Bengalis. For example, the man just quoted continued, "We Nepalis treat them equally. In other

\footnotetext{
${ }^{6}$ It should be noted, however, that son preference was probably never as strong in Pariwarbasti as it was in other areas in India, such as the Punjab.

${ }^{7}$ Not all of the respondents answered questions on son preference because I started asking it after data collection had already begun.
} 
castes, like in Muslim communities, there is discrimination, but it is decreasing these days.”

Respondents who said daughters are preferred explained that sons demand more material goods from parents, use drugs and alcohol, and can no longer be depended on in old age, while daughters do not engage in such behaviors and love their parents more. For example, a 26-year-old married woman noted that, "parents prefer daughters these days because sons are violent. They are aggressive towards their parents sometimes". The degeneration of sons and the contrast with the loving support of daughters was also a common topic in informal conversations.

Most respondents suggested that the relatively equal valuation of sons and daughters presents a shift from the past. Sixteen of the 26 respondents that were asked about son preference in the past noted that boys were preferred in the past. As another 26-year-old married woman described:

"According to our grandparents, there was a culture of liking sons. If they produced many sons, they were happier. They hoped to produce a son. ... It's said in Nepali that girls are for holding another's house. It means [girls] belong to others and they have to work there. So these are the reasons girls were disliked. ... [But] it's not like that now. People have changed their concept. Daughters can do better than a son these days."

Interestingly, of the remaining six respondents who said there had not been a change over time, all of them said sons and daughters had been equal in the past, as well as the present. This belief may reflect in part the greater equality between sons and daughters among Nepalis as compared to other Indian groups.

\subsection{Education}

In Pariwarbasti educating children is an extremely important goal for parents. In 2007-2008 I asked people what their hopes were for the future and nearly everyone said that giving their children a good education was their main goal. Further, countless casual conversation with parents turned to the stresses and aspirations of educating children. Education presents substantial costs to parents, including both direct and opportunity costs. The government provides free Nepali-medium schooling up to class eight in Pariwarbasti, but parents must still pay for uniforms and textbooks and give up their children's labor at home. Paying for extra tutoring by older students outside regular school hours, known as "tuition", is also common among wealthier families. Further, nearly everyone I spoke with wanted to send their children to private Englishmedium schools. There is one small English-medium school in the village for elementary school children and several other English-medium schools in Kalimpong. 
Wealthier families paid to send their children to English-medium schools in Kalimpong, sometimes incurring not only substantial tuition costs but also transportation or hostel costs.

Educational attainment and the value of education appear to have increased dramatically over time for both genders in Pariwarbasti. However, it also appears that it is increasing faster for girls, resulting in a decline in the gender gap. Older women in the village did not attend school at all or went for a couple of years at most. Instead their parents kept them at home to look after younger siblings and help with work around the home and in the fields. As one 38-year-old woman described:

"When I asked to go to school, my father told me, 'Why do you need to write a letter? You are going to another's house.' ... My brothers were educated, my younger sisters got some level of education, class 5 , class 6 , but I could not even write my name. ... I had to do all the village work and look after all the cows and goats.”

In keeping with this pattern, I had difficulty finding a woman in the oldest life course stage with ten years of schooling to interview. Conversely, today's generation of daughters attend school for several years. In fact, I could not find an unmarried woman with less than nine years of education to interview. (However, part of my trouble was due to the pattern of girls usually stopping their education when they marry. So, the young women with low levels of education are married.) By contrast, the differences among cohorts of men did not seem as large as those among women. Unlike the older women, most of the older men in the village had at least a few years of education. It appears that there is little to no difference in parents sending sons and daughters to school these days. However, boys may stay in school longer because girls marry at a younger age and usually leave school if they marry.

Respondents spoke straightforwardly about changes in education over time. As one 51-year-old man remarked, “In the past, daughters weren't given education. Only the sons were given education. At our time also, education wasn't for daughters. Our sisters didn't get a chance to read. Daughters weren't important, but these days education is needed for both sons and daughters." Similarly, a young married woman said, "In the past people didn't send their daughters to school. They used to send only their sons to school. They used to think that daughters would work at home and the sons would go to school, but this old concept is not there now."

\subsection{Marriage and premarital relationships}

Most marriages that took place in the recent past in Pariwarbasti were arranged by parents and other relatives. The boy's family would approach the girl's family, the families would come to an agreement, the girl was asked for her consent, and the couple 
was married. Often the couple did not know each other before they married or knew each other very little, although the boy may have played a role in choosing the girl. For example, as one 52-year-old woman stated when describing her own arranged marriage at age 15, "Well, in the earlier times it used to be like that, whomever the parents would get for us we had to marry that person".

Today, however, the common way to marry is for young couples to elope without the knowledge and consent of their parents. All 30 respondents spoke of this change in marriage practices and described how elopements have become widespread. In Pariwarbasti these marriages are referred to in Nepali as "keti bagyo" (literally, the girl ran away) and in English as "love marriages." In these marriages, the girl runs away from her family home to the boy's home without her parents' knowledge or both the boy and girl run away to a friend or other relative's home without any of their parents knowing. Usually, after a few days of living together they inform their parents, return to the boy's home if necessary, and formally marry later on.

Elopements are often preceded by premarital relationships between young people. Openly dating or spending time alone together is still not acceptable in the village. Therefore young people often keep such relationships a secret, especially from their parents. However, young men and women are allowed to mix relatively freely in groups and I knew of two families in which unmarried couples openly visited each other's homes. One 48-year-old woman contrasted the freedom of unmarried daughters today with a stricter environment when she was young:

"Our parents did not allow us to go to friends' houses. They did not allow us to speak much or to go out. Now that has changed. We were not allowed to make boyfriends or bring them home. Now it is not like that. Today, boys and girls become friends, go out, and visit each other's houses."

These premarital relationships sometimes include premarital sex. During my time in Pariwarbasti I attended a handful of weddings, in most cases the bride was pregnant or had already had a child. A few of the young women in my sample from 2007-2008 had also had a child before marriage. They eloped and started living with their husband when they were pregnant, but did not formally marry until after the child was born for religious reasons. ${ }^{8}$ These observations led me to suspect that premarital pregnancies are relatively common in Pariwarbasti. When asked about premarital pregnancies in 2010, respondents said premarital pregnancies are increasing and, according to a few

\footnotetext{
${ }^{8}$ Hindus in Pariwarbasti believe that if a man marries a woman that is pregnant with a female fetus, he is marrying the child as well as the mother when he places the sindur and poteon the bride during the ceremony. Sindur is a red power placed in the part of a bride's hair by the groom during the wedding ceremony and worn after marriage by women as a symbol of their married status. Pote is a necklace placed around the bride's neck by the groom during the ceremony. Villagers told me that some Buddhists also do not marry when the woman is pregnant out of deference to the Hindu tradition.
} 
respondents, even widespread. As one 21-year-old woman described, "[Young women] didn't even get a chance to see their husbands before marriage before. But nowadays, mostly the girls become pregnant before their marriage. As soon as they marry, they give birth to their child." Only four respondents said that young women do not become pregnant before marriage these days, all of whom were members of the oldest generation.

Two respondents suggested, of their own accord, that the availability of contraception and abortion is facilitating premarital sex in the village. One unmarried man suggested that premarital sex has increased because contraception reduced the fear of pregnancy:

"Now, [premarital pregnancies] are increasing because in the past there were not modern techniques. In the past they used to fear to have sexual relations. There was not such preventive means that are found now. But now, due to the use of preventive means, the boys and girls aren't afraid to have sexual relations. They think if by mistake they have a pregnancy they will have an abortion."

Similarly, the other respondent, a 55-year-old woman, noted that, "The girls these days are very clever. Even if they are pregnant, they go to hospitals themselves for abortion. In the past, we didn't have this knowledge. There are many cases of abortions and the girls look as fresh as before, but I think it's not good to do so." However, as noted above, I believe it is unusual for unmarried women to use contraception. The many visible pregnancies suggest that abortion is not that common either.

While unmarried youth have greater sexual freedom than in the past, it is still not entirely acceptable for young women. If an unmarried woman becomes pregnant and marries, the village seems to tolerate the situation with equanimity. Certainly she will be the subject of gossip, but any elopement gives rise to at least some gossip. If she does not marry, however, she bears the brunt of society's displeasure. As the 21-yearold woman quoted above went on to describe:

"When she is pregnant if she is left by her boyfriend what can she do? If she is accepted [by her boyfriend], it's all right. Otherwise, she will be condemned. Everyone criticizes her. This is an asocial act. We talk about and criticize such incidents. ... The girls are insulted a lot. Boys are not criticized in the way the girls are. The physical changes are seen in girls, not in boys.”

A few respondents also noted that in the worst cases some girls in the region have committed suicide. As a 24-year-old man described:

"In this case, most of them get married as soon as possible. They don't tell others. They run away and get married, but some boys aren't ready to marry the girl. In this situation, we can see some girls commit suicide and a few live their life struggling with society. Society does not see it as a good practice.” 


\subsection{Parental support in old age}

Once parents are older it is customary for a son and his wife to care for them. Thus, unlike sons, daughters do not support their own parents in old age, but instead are expected to care for their parents-in-law in their role as daughters-in-law. However there are indications that this custom may be eroding in strength in Pariwarbast. Thirteen of the respondents said that daughters are more actively taking care of their parents in old age than in the past, while nine respondents said that the norm of sons taking care of parents is the same as it was in the past. ${ }^{9}$

The thirteen respondents who said daughters are taking a more active role caring for parents emphasized the quality of support that daughters give their parents. As described above in reference to son preference, they attributed daughter's high quality care to loving their parents more than sons. For example, as one 38-year-old man described, "Yes, [a daughter] does [take care of her parents] better than a son. Here also we can see some daughters who are looking after their old parents. They are keeping them in a better condition than sons." Similarly, a 51-year-old man noted, "Yes, many [daughters take care of their parents]. More than a son. The sons have forgotten their parents. It is the daughters who look after them well.” They also contrasted daughters caring for parents these days with the custom of parents not being able to accept support from daughters in the past. For example, a 21-year-old woman noted, "In the past, [daughters] didn't use to do that. At that time a kind of condition was there in which the parents used to think that they shouldn't eat at their daughter's house, they shouldn't take the wealth of their daughters."

By contrast, respondents who said that there was not a change emphasized the continued customary obligation of women to their in-laws. For example, as one 24year-old man said, "Some [daughters] are interested in looking after their parents, but most of them can't do it despite their interest. They have to take care of their families. The situation is not favorable. She should give first priority to her parents-in-law because her real home is the home of her parents-in-law.” Interestingly, however, two of these respondents also noted that when there is not a son, daughters do care for their parents. As one 27-year-old man noted, "If no sons are there and only daughters are there and the parents are older then [daughters] look after their parents. But generally [daughters] look after their husband and mother-in-law and father-in-law more than their own parents."

\footnotetext{
${ }^{9}$ Of the remaining respondents, five said they did not know what it was like in the past and three did not answer or were not asked the question.
} 


\section{Discussion and conclusion}

I motivated this paper by suggesting that fertility decline may transform the relative value and roles of sons and daughters. Specifically, the decline in the value of large numbers of children and the effective means of fertility control that underlie fertility decline should lead to greater freedom of daughters. Further, the rise in the proportion of families with children of only one gender and the smaller number of children in families should create pressures for greater gender symmetry between sons and daughters. To examine this theoretical model, I explored the perceptions of changes over time in family behaviors in Pariwarbasti, a context in which fertility was at the replacement level a decade ago.

The results provide evidence of changes in the relative value and treatment of sons and daughters. These changes are largely consistent with the theorized effects of fertility decline, suggesting that Pariwarbasti is moving toward greater gender symmetry between sons and daughters. Son preference appears to be declining with people valuing daughters increasingly equally to sons. The gender gap in education is also closing. Parents believe more in the importance of sending daughters to school, just like sons. Finally, daughters may be taking on more of the customary role of sons by caring for their parents in old age. The evidence on this last point on parental support is less compelling, however, since there were a substantial number of respondents who believed that daughters are not becoming more like sons in this respect. Intriguingly though, even respondents who said parental support is not changing said that daughters take care of parents when there is no son - a situation that will inevitably increase over time with fertility decline. Further, the shifts in parental support should take place after those in son preference, education, and marriage. Thus, the weaker evidence for changes in parental support is consistent with the timing of the theoretical model.

The results also point to the greater freedom of unmarried daughters, which is consistent with declining fertility reducing the motivation to control women's sexuality. Parents, as well as the community at large, are increasingly allowing boys and girls to interact more freely with each other. Young men and women are also increasingly engaging in premarital relationships, although these relationships are still disapproved of by most parents, especially for daughters. Greater sexual freedom can also be seen in the tolerance of the community towards premarital pregnancies when the couple marries. However, the community is not tolerant of pregnant women remaining unmarried. Thus, while daughters' sexual freedom has increased over time, their sexuality is still controlled in many ways and they pay a greater price than their partners if they become pregnant and don't marry. Thus, this points to greater, but far from complete gender symmetry between sons and daughters. 
Overall, there is compelling evidence that the gender system did change as fertility declined. Demonstrating this is necessary but insufficient to show that fertility decline contributed to the changes in the gender system. It is also necessary to show that fertility decline made a unique causal contribution to changes in the gender system. With these data it is impossible to determine what causal role, if any, fertility decline and control played in the changes in the gender system. The only direct evidence that it played a unique causal role came from the two respondents who said that young people are increasingly engaging in premarital sex because contraception and abortion allow them to do so with less fear of becoming pregnant. These comments are remarkably consistent with the pathway of fertility control increasing women's sexual freedom by separating sex from childbearing. However, since unmarried women do not appear to actually use contraception or abortion in very large numbers, it may be that they have encouraged young people to think they can have sex without fearing the consequences. In other words, people believe they can start using contraception at any time to prevent pregnancy or resolve any pregnancies with an abortion, but in practice they do not end up doing so.

The lack of compelling evidence that fertility decline played a unique role in contributing to the changes in the gender system is compounded by other factors that are also working to transform gender systems. Respondents themselves said that the changes in family behaviors were caused by the spread of mobile phones and televisions, Bollywood movies, foreign influence, and educational expansion. Scholarly research also shows that such factors do reduce son preference and arranged marriages and lead to other changes in family behaviors (Barber and Axinn 2004; Bhat and Zavier 2003; Chung and Das Gupta 2007; Ghimire et al. 2006). Further, national and community level development programs may also have contributed to changes in the gender system. To my knowledge, there are no local programs that focus on gender equality or empowering women specifically in Pariwarbasti. However, there are local savings groups that women participate in and the area has participated for several years in the Integrated Child Development Services program, which provides employment to a handful of local women as well as health information and services. Thus, the chief limitation of this paper is that it does not provide compelling evidence that fertility decline provided a causal contribution to transforming the gender system. Providing evidence of a causal role will be difficult, however, and require multi-level data collected in multiple places and times (Mason 1997). Thus, an important area for future research is examining whether fertility decline does play a causal role in transforming gender systems.

Despite this limitation, this paper makes an important contribution to the broad question of whether and how fertility decline and control transform gender systems. First, by focusing on sons and daughters in the family, it makes a theoretical 
contribution by describing how changes in the gender composition of families may be an important pathway of change. In particular, the substantial proportion of families with only daughters that will arise in low fertility contexts may present a fundamental threat to patrilineal family systems that underlie gender systems in many places. Thus, this paper describes how fertility decline may plausibly contribute to greater symmetry between sons and daughters. Second, by using semi-structured interviews from one village, this paper provides a detailed exploration of how people in one place experienced and perceived changes in fertility and the gender system. It also suggests specific areas where such changes in the gender system can be measured and tested in the future with survey data from South Asia and similar contexts. Future research should test whether fertility decline and control leads to less fear of pregnancy, and thus more sexual freedom, less son preference, and greater parental support from daughters.

\section{Acknowledgments}

The author would like to thank Anju Malhotra, Karen Mason, Rohini Pande, Kirsten Stoebenau, Kathryn Yount, and other members of the Fertility and Empowerment Network for their helpful comments. The author would also like to thank Christophe Z. Guilmoto for generously providing his calculations of the child-woman index for districts in West Bengal and Sikkim. The data collection and transcription for this study were supported by a grant from the Population Studies Center at the University of Michigan. This study was also supported by the International Center for Research on Women (ICRW) and The William and Flora Hewlett Foundation. A previous version of this paper was presented at the Annual Meeting of the Population Association of American in San Francisco, CA on May 5, 2012. 


\section{References}

Arnold, F., Choe, M.K., and Roy, T.K. (1998). Son preference, the family-building process and child mortality in India. Population Studies: A Journal of Demography 52(3): 301-315. doi:10.1080/0032472031000150486.

Axinn, W.G. and Pearce, L.D. (2006). Mixed method data collection strategies. New York: Cambridge University Press. doi:10.1017/CBO9780511617898.

Bailey, M.J. (2006). More power to the pill: The impact of contraceptive freedom on women's life cycle labor supply. Quarterly Journal of Economics 121(1): 289-320.

Barber, J.S. and Axinn, W.G. (2004). New ideas and fertility limitation: The role of mass media. Journal of Marriage and the Family 66(5): 1180-1200. doi:10.1111/j.0022-2445.2004.00086.x.

Bhat, P.N.M. (1996). Contours of fertility decline in India: A district-level study based on the 1991 census. In: Srinivasan, K. (ed.). Population policy and reproductive health. New Delhi: Hindustan Publishing Corporation: 96-177.

Bhat, P.N.M. and Zavier, A.J.F. (2003). Fertility decline and gender bias in northern India. Demography 40(4): 637-657. doi:10.2307/1515201.

Bloom, D.E., Canning, D., Fink, G., and Finlay, J.E. (2009). Fertility, female labor force participation, and the demographic dividend. Journal of Economic Growth 14(2): 79-101. doi:10.1007/s10887-009-9039-9.

Chakraborty, T. and Kim, S. (2010). Kinship institutions and sex ratios in India. Demography 47(4): 989-1012. doi:10.1007/BF03213736.

Chung, W.J. and Das Gupta, M. (2007). The decline of son preference in South Korea: The roles of development and public policy. Population and Development Review 33(4): 757-783. doi:10.1111/j.1728-4457.2007.00196.x.

Das Gupta, M. and Bhat, P.N.M. (1997). Fertility decline and increased manifestation of sex bias in India. Population Studies: A Journal of Demography 51(3): 307-315. doi:10.1080/0032472031000150076.

Das Gupta, M., Chung, W.J., and Li, S.Z. (2009). Evidence for an incipient decline in numbers of missing girls in China and India. Population and Development Review 35(2): 401-416. doi:10.1111/j.1728-4457.2009.00285.x. 
Desai, S. (1995). When are children from large families disadvantaged? Evidence from cross-national analyses. Population Studies: A Journal of Demography 49(2): 195-210. doi:10.1080/0032472031000148466.

Engelhardt, H., Kogel, T., and Prskawetz, A. (2004). Fertility and women's employment reconsidered: A macro-level time-series analysis for developed countries, 19602000. Population Studies: A Journal of Demography 58(1): 109-120. doi:10.1080/0032472032000167715.

Ghimire, D.J., Axinn, W.G., Yabiku, S.T., and Thornton, A. (2006). Social change, premarital nonfamily experience, and spouse choice in an arranged marriage society. American Journal of Sociology 111(4): 1181-1218. doi:10.1086/498468.

Goodkind, D. (2011). Child underreporting, fertility, and sex ratio imbalance in China. Demography 48(1): 291-316. doi:10.1007/s13524-010-0007-y.

Grant, M.J. and Behrman, J.R. (2010). Gender gaps in educational attainment in less developed countries. Population and Development Review 36(1): 71-89. doi:10.1111/j.1728-4457.2010.00318.x.

Guilmoto, C.Z. and Rajan, S.I. (2001). Spatial patterns of fertility transition in Indian districts. Population and Development Review 27(4): 713-738. doi:10.1111/ j.1728-4457.2001.00713.x.

Guilmoto, C.Z. and Rajan, S.I. (2002). District level estimates of fertility from India's 2001 census. Economic and Political Weekly 37(7): 16-22.

Guilmoto, C.Z. (2009). The sex ratio transition in Asia. Population and Development Review 35(3): 519-549. doi:10.1111/j.1728-4457.2009.00295.x.

International Institute for Population Sciences (IIPS) (2010a). District level household and facility survey (DLHS-3), 2007-2008: India - West Bengal. Mumbai: IIPS.

International Institute for Population Sciences (IIPS) (2010b). District level household and facility survey (DLHS-3): India. Mumbai: IIPS.

International Institute for Population Sciences (IIPS) and Macro International (2007). National family health survey (NFHS-3), 2005-2006: India. Mumbai: IIPS.

Malhotra, A. (2009). Remobilizing the gender and fertility connection: The case for examining the impact of fertility control and fertility decline on gender equality. Paper presented at the International Union for the Scientific Study of Population Meeting, Marrakech, Morocco, September 28, 2009. 
Mason, K.O. (1997). Gender and demographic change: What do we know? In: Jones, G.W., Douglas, R.M., Caldwell, J.C., and D'Souza, R.M. (eds.). The continuing demographic transition. Oxford: Clarendon Press: 158-182.

Mason, K.O. (2001). Gender and family systems in the fertility transition. Population and Development Review 27:160-176.

Matysiak, A. and Vignoli, D.(2008). Fertility and women's employment: A metaanalysis. European Journal of Population / Revue Européenne De Démographie 24(4): 363-384. doi:10.1007/s10680-007-9146-2.

Mishra, V., Roy, T.K., and Retherford, R.D. (2004). Sex differentials in childhood feeding, health care, and nutritional status in India. Population and Development Review 30(2): 269-295. doi:10.1111/j.1728-4457.2004.013_1.x.

Morgan, S.P. and Niraula, B.B. (1995). Gender inequality and fertility in two Nepali villages. Population and Development Review 21(3): 541-561. doi:10.2307/ 2137749 .

Pande, R.P. (2003). Selective gender differences in childhood nutrition and immunization in rural India: The role of siblings.Demography 40(3): 395-418. doi:10.1353/dem.2003.0029.

Presser, H.B. (2001). Comment: A gender perspective for understanding low fertility in post-transitional societies. Population and Development Review 27:177-183.

Registrar General [India] (1997). District level estimates of fertility and child mortality for 1991 and their inter relations with other variables. New Delhi, India: Registrar General.

Registrar General [India] (2002). Sample Registration System bulletin. New Delhi, India: Registrar General.

Registrar General [India] (2009). Sample Registration System bulletin. New Delhi, India: Registrar General.

Reher, D.S. (2011). Economic and social Implications of the demographic transition. Population and Development Review 37(S1): 11-33. doi:10.1111/j.1728-4457. 2011.00376.x.

United Nations (2011). World population prospects, the 2010 revision. New York: Population Division, United Nations. 
Allendorf: Fertility decline and the transformation of gender systems in the family

Ye, H. and Wu, X. (2011). Fertility decline and educational inequality in China. Paper presented at the Annual Meeting of the Population Association of America, Washington, DC, April 1, 2011. 
Demographic Research: Volume 27, Article 16 